\title{
Corporate Social Activities of Private Commercial Banks in Bangladesh: An Evaluation
}

\section{Ferdouse Ara Tuli}

Senior Lecturer, Faculty of Business, ASA University Bangladesh, BANGLADESH

\begin{abstract}
Every business organization has some responsibilities to the people because organizations need people to sell their products. No organization can make profit without selling products to the customers. However, every bank needs customers to sell products for earning profits. In this case, the authority of each bank should accomplish some activities for the well-being of the people in the society. Thus, this paper attempts to evaluate the corporate social activities of private commercial banks in Bangladesh. This paper also tries to explore the problems of corporate social activities accomplished by the private commercial banks in Bangladesh and suggests some measures to enhance the performance of the banks while they are accomplishing social activities for the people in the society.
\end{abstract}

Keywords: Corporate, Social, Bank, People, Bangladesh.

\section{INTRODUCTION}

○ orporate social activity or corporate social responsibility means organizations integrate social and environmental concerns in business operations and their interaction with business relevant groups on a voluntary basis. It is about how organizations take responsibility for their stakeholders. It can be viewed as a comprehensive set of policies, practices, and programs that are integrated into business operations, supply chains, and decision making process throughout the company and include responsibilities for current and past actions as well as adequate attention to future impacts. It focuses vary by businesses, by size, by sector and even by geographic region. It increases the business profitability and preserves interest of all stakeholders.

One of the fastest growing and developed sectors of Bangladesh is the banking sector. The numbers of banks are increasing gradually in Bangladesh. At present, there are thirty domestic private commercial banks, four state-owned commercial banks, four government-owned specialized development banks, nine foreign commercial banks operating their business activities in Bangladesh. Since the numbers of banks are increasing, the competition among these banks is also increasing. In this case, the bank can attract customers to the products by accomplishing various social activities.

The purpose of the study is to examine the social activities of private commercial banks in Bangladesh. In this case, the author has taken five first-generation commercial banks in Bangladesh through purposive sampling.

\section{Objectives of the Study}

The study has been conducted with the following objectives:

- To investigate the corporate social activities of first generation private commercial banks of Bangladesh
- To evaluate the corporate social activities accomplished the first generation private commercial banks of Bangladesh

- To find out the problems (if any) relating to the corporate social activities performed the first generation private commercial banks of Bangladesh

- To recommend some suggestions based on findings

\section{Methodology of the Study}

The author has taken five first-generation private commercial banks of Bangladesh such as AB Bank Ltd, City Bank Ltd., IFIC Bank Ltd., National Bank Ltd., and United Commercial Bank Ltd. as sample size in this study. The primary data has been collected from the bankers and customers of sample private commercial banks through face-to-face interview and informal discussion. The secondary data has been collected from the following sources:

- Annual Reports of the Banks

- Website of the banks

- Published different books, articles, journals, magazines, etc.

\section{LITERATURE REVIEW}

In recent times, the most-talking terminology is the corporate social responsibility. It is preventing by corporate world, commercial community and capitalistic industry. It is becoming one of the determining factors for market access. According to the United Nations Industrial Development Organization, "corporate social responsibility understood as being economic, environmental and social imperatives (Triple-Bottom-Line-Approach), while at the same time address the expectation of shareholders and stakeholders. Corporate social responsibility is a concept whereby companies integrate social and environmental concerns in 
their business operations and their interactions with their stakeholders on a voluntary basis. Green paper ( 2001) identified that social responsibility means not only fulfillment legal expectations but also going beyond compliance and investing ' more' into human capital, the environment and in rapport-building of activity.

Kok et. al ( 2001) told that corporate social responsibility is the obligation of the firm to use its resources in ways to benefit society, through committed participation as a member of society, taking into account the society at large and improving the welfare of society at large independently of direct gains of the company. Smith (2002) pointed out that corporate social responsibility is the integration of business operations and values whereby the interests of all stakeholders, including customers, employees, investors, and the environment are reflected in the organization's policies and actions.

\section{MEANing of CoRporate Social ResponsibILITY}

Corporate social responsibility usually refers to the objectives or motives that should be given weight by the business in addition to those dealing with economic performance (e.g. profits). It implies that business decision makers recognize some obligations to protect and improve the welfare of society as a whole along with their interests. It net effect is to enhance quality of life and bring about harmony between business actions and society's wants.

\section{Dimensions of Corporate Social Responsibility}

There are two dimensions of corporate social responsibility. These are as follows:

- Internal dimension: The corporate social responsibility has some internal dimensions such as human resources management, health and safety at work, adaptation to change and management of environmental impact and natural resources.

- External dimensions: The corporate social responsibility has some external dimensions such as local communities, business partners, suppliers and customers, human rights, and global environmental concerns.

Importance of Practicing Corporate Social Responsibility The importance of practicing corporate social responsibility are as follows:
- Treat employees fairly and with respect

- Operate with integrity and in an ethical manner in all its business dealings with customers, suppliers, lenders, and others

- Respect human rights

- Sustain the environment for future generations

- Be a responsible neighbor in the community ' corporate citizen'

Corporate Social Activities of the First-Generation Private Commercial Banks of Bangladesh

The corporate social activities of the first-generation private commercial banks of Bangladesh are shown in the following table:

Table-1: List of Corporate Social Activities of First Generation Banks of Bangladesh

\begin{tabular}{|c|c|c|}
\hline Sl. & Name of the Banks & $\begin{array}{l}\text { Corporate Social } \\
\text { Activities }\end{array}$ \\
\hline 1. & AB Bank Ltd.( ABBL) & $\begin{array}{l}\text { a) Health } \\
\text { p) Education } \\
\text { e) Social Welfare } \\
\text { d) Sports }\end{array}$ \\
\hline 2. & City Bank Ltd. ( CBL) & $\begin{array}{l}\text { a) Environment } \\
\text { p) Health } \\
\text { f) Disaster relief } \\
\text { d) Social welfare }\end{array}$ \\
\hline 3. & $\begin{array}{l}\text { International \&inance } \\
\text { Investment \& Commerce } \\
\text { Bank Ltd. ( IFICBL) }\end{array}$ & $\begin{array}{l}\text { a) Education } \\
\text { b) Health } \\
\text { f) Art \& culture } \\
\text { d) Poverty reduction } \\
\text { e) Disaster relief } \\
\text { f) Social welfare }\end{array}$ \\
\hline 4. & $\begin{array}{l}\text { National Bank Ltd. } \\
\text { (NBL) }\end{array}$ & $\begin{array}{l}\text { a) Education } \\
\text { b) Financial Inclusions } \\
\text { f) Disaster relief } \\
\text { d) Sports } \\
\text { e) Social welfare }\end{array}$ \\
\hline 5. & $\begin{array}{l}\text { United Commercial } \text { Bank } \\
\text { Ltd.( UCBL) }\end{array}$ & $\begin{array}{l}\text { a) Disaster relief } \\
\text { p) Health } \\
\text { f) Social welfare } \\
\text { d) Sports }\end{array}$ \\
\hline
\end{tabular}

Source: Bangladesh Bank Report December, 2012

Direct Corporate Social Expenditures of Five First Generation Private Commercial Banks of Bangladesh (2008-2012)

\begin{tabular}{|l|l|l|l|l|l|c|}
\hline S1. & Name of the Banks & \multicolumn{5}{c|}{ Amounts in Tk. (Crore) } \\
\cline { 3 - 7 } & & 2008 & 2009 & 2010 & 2011 & 2012 \\
\hline 1. & AB Bank Ltd.( ABBL) & - & - & $50,200,000$ & $29,830,000$ & $34,086,000$ \\
\hline 2. & City Bank Ltd. (CBL) & - & $4,980,000$ & $11,703,000$ & $1,351,500$ & $5,676,734$ \\
\hline 3. & $\begin{array}{l}\text { International Finance Investment \& } \\
\text { Commerce Bank Ltd. (IFICBL) }\end{array}$ & $10,559,000$ & - & $11,700,000$ & $17,700,000$ & $43,139,895$ \\
\hline 4. & National Bank Ltd. (NBL) & $47,269,000$ & $68,404,000$ & $142,350,000$ & $36,822,000$ & $53,612,000$ \\
\hline 5. & United Commercial Bank Ltd.(UCBL) & - & - & $16,059,000$ & $46,500,000$ & $41,438,000$ \\
\hline
\end{tabular}


The above table implies the direct corporate social expenditures of five first generation private commercial Bangladesh, the National Bank Ltd. regularly expends a substantial amount of money for the well-being of the society as a part of their corporate social responsibilities. The AB Bank Ltd. does not regularly expend money for the development of the society and their performance in terms of money expended to the various social activities is lower among the five first-generation private commercial banks of Bangladesh. The City Bank Ltd., IFIC Bank Ltd, and United Commercial Bank Ltd. moderately expend money as a part of their corporate social responsibility in various activities of the society.

\section{RECOMMENDATIONS}

The following measures are suggested to the authorities of five first-generation private commercial banks of Bangladesh to enhance their corporate social activities:

- The authority of the AB Bank Ltd. should give more emphasis on the corporate social activities in the future if the authority of the bank wants to attract customers to the products and services of the bank.

- Although the corporate social activities of the national Bank Ltd. are comparatively good than other firstgeneration private commercial banks of Bangladesh but the authorities of the bank should explore more fields where they can contribute to develop the society that will help them to attract prospective customers to their products and services

- The authorities of the City Bank Ltd., IFIC Bank Ltd. and United Commercial Bank Ltd. should give top priority on the corporate social activities immediately otherwise they may not be able to attract large number of customers to their products and services in the longrun.

- The authorities of the five first-generation private commercial banks of Bangladesh should set standard for conducting social responsibilities and should spend a certain portion of their profits regularly as budget for social activities.

- The authorities of the five first generation private commercial banks of Bangladesh should conduct occasional social audits for using funds properly to reach the social-responsibility goals of the bank.

\section{CONCLUSION}

Corporate social responsibility is becoming popular due to the influence of globalization. People are becoming conscious about their rights and benefits. So, organizations apply and practice the corporate social techniques to create a positive impression about their businesses in the minds of the customers. The banking business is a service oriented business. If a bank wants to create a positive impression in banks of Bangladesh during the year 2008-2012. Among the five first-generation private commercial banks of the minds of the customers about their products and services, the bank needs to perform corporate social activities. At present, the authority of the five firstgeneration private commercial banks needs to give more emphasis on their corporate social activities. They also need to expand their corporate social activities in the future to attract the prospective customers to their products and services.

\section{REFERENCES}

Adams, Carol, and Zutshi, Ambika, (2006), "Corporate Social Responsibility: Why Business Should Act Responsibility and Be Accountable", The Cost and Management, Vol. 34, No. 4, July-August, Pp. 5-17.

Ahmed AA and Dey MM. 2011. Accounting Disclosure Scenario: An Empirical Study of the Banking Sector of Bangladesh Accounting \& Management Information Systems, 9.

Ahmed AA, Dey MM, Akhter W and Raza A. 2011. Timeliness attributes and the extent of accounting disclosure: a study of banking companies in Bangladesh Interdisciplinary Journal of Contemporary Research in Business, 3, 915-925.

Ahmed AA, Khan W and Hossain MS. 2011. Reporting Practice of Accounting Disclosure on Changes in Listed Companies of Bangladesh ASA University Review, 5, 83-96.

Ahmed AA, Siddique MN and Masum AA. 2013. Online Library Adoption in Bangladesh: An Empirical Study University of Bahrain Best Practices in Management, Design and Development of e-Courses: Standards of Excellence and Creativity. Manama: IEEE.

Ahmed AA. 2012. Disclosure of Financial Reporting and Firm Structure as a Determinant: A Study on the Listed Companies of DSE ASA University Review, 6, 44-60.

Ahmed, A. A. A., \& Neogy, T. K. Merger and Acquisitions (M\&A) Goodwill Accounting: Principles and Practice The Bangladesh Accountant, ICAB, Vol 65 No. 36, Oct-Dec 2009

Arif, Anwarul, Azim, (1990), "Social Responsibility of Business" Chittagong University Studies (Commerce), Vol. 6, pp. 73-94.

Ruggie, John, G, (2000), "Globalization, the Global Impact and Corporate Social Responsibility", Transnational, Pp. 291-294.

\section{Websites}

Development of Environment, Government of Bangladesh: www.doe.bd.org

United Nations Environment Programs: www.unep.org

Sustainable Development Networking Program (SDNP) Bangladesh: www.sdnbd.org

Bangladesh Bank Website: www.bangladeshnbank.org.bd

Website of AB Bank Ltd.: www.abbank.org

Website of City Bank Ltd.: www.cbl.org

Website of IFIC Bank Ltd.: www.ificbank.org

Website of National Bank Ltd.: www.nbl.org

Website of United Commercial Bank Ltd.: www.ucbl.org 